\title{
HUBUNGAN SELF-DETERMINATION DAN MOTIVASI BERPRESTASI DENGAN KEMAMPUAN PENGAMBILAN KEPUTUSAN SISWA SMA
}

\author{
Henny Christine Mamahit ${ }^{1}$ \\ Program Studi Bimbingan Konseling Unika Atma Jaya \\ henny.christine@atmajaya.ac.id \\ Dominikus D. Biondi Situmorang ${ }^{2}$ \\ Program Studi Bimbingan Konseling Unika Atma Jaya
}

\begin{abstract}
Career decision-making ability requires the ability to assess and think of the integration between the knowledge of themselves and the knowledge of the job. Self-determination is the ability to identify desire for autonomy, competence, and relation in order to achieve a target. Achievement motivation refers to students' attempts to meet goals by becoming a moderate risk taker, showing perseverance in work, having expectation for feedback, showing responsibility in a given task, and having the ability to innovate. The objective of this research is to analyze the effect of self-determination and achievement motivation on Senior High School students' career decision-making ability. This research also investigates if the aforementioned variables are correlated. The sample for this research are 410 students of Senior High School Grade XI. This is a quantitative based research with multiple correlational research design. The results of the research shows that the correlation value between the selfdetermination and achievement motivation variables and the career decision-making ability variable is $0.780(0.00<0.05)$. This means that there is a significant correlation between the aforementioned variables. The contribution of the self-determination and achievement motivation variables to the career decision-making ability variable $\left(\left(R^{2}\right)\right.$ is $78 \%$.
\end{abstract}

Keywords: career decision-making abilities; self-determination; achievement motivation.

\begin{abstract}
ABSTRAK
Kemampuan pengambilan keputusan karir adalah kemampuan siswa terkait proses penilaian dan pemikiran dalam mengintegrasikan pengetahuan tentang dirinya dengan pengetahuan suatu pekerjaan untuk membuat pilihan karir. Self determination adalah kemampuan diri dalam mengidentifikasi keinginan yang berkaitan dengan otonomi, kompetensi, dan relasi dalam rangka mencapai tujuan. Motivasi berprestasi dijelaskan sebagai usaha siswa untuk mencapai tujuan dengan cara berani mengambil resiko secara moderat, memiliki ketekunan dalam mengerjakan tugas, memiliki harapan terhadap umpan balik, memiliki tanggung jawab terhadap kinerja, dan memiliki kemampuan dalam melakukan inovasi. Tujuan dalam penelitian ini adalah untuk memberikan gambaran dan menganalisa hubungan dan pengaruh self determination dan motivasi berprestasi terhadap pengambilan keputusan karir siswa SMA. Populasi dari penelitian ini adalah siswa kelas XI dari lima SMA Swasta, dengan sampel sebanyak 410 siswa. Penelitian menggunakan metode penelitian kuantitatif dengan jenis penelitian multiple correlation. Hasil korelasi antara variabel self determination dan motivasi berprestasi dengan kemampuan pengambilan keputusan karir menghasilkan korelasi sebesar 0,780 dengan signifikan sebesar 0,00 pada level signifikansi 0,05 . Dikarenakan $P$-value $=0,00$ lebih besar dari $\alpha=0,05$, hasil ini menunjukkan bahwa terdapat korelasi positif yang signifikan antara variabel self determination dengan motivasi berprestasi terhadap kemampuan pengambilan keputusan karir. Variabel self determination dan motivasi berprestasi memberikan kontribusi sebesar $78 \%\left(\mathrm{R}^{2}\right)$ terhadap variabel kemampuan pengambilan keputusan karir.
\end{abstract}

Kata kunci: kemampuan pengambilan keputusan karir; self determination; motivasi berprestasi. 


\section{PENDAHULUAN}

\subsection{Latar Belakang}

Manusia terlahir dengan sebuah tujuan hidup. Disadari maupun tidak, dalam berperilaku, manusia diarahkan untuk mencapai suatu tujuan. Siswa selain dikenal sebagai manusia sosial, siswa atau pelajar dipandang juga sebagai seorang individu yang dilahirkan dengan suatu tujuan tertentu.

Siswa yang sadar akan tujuan dalam hidupnya, terpacu untuk mencapai tujuan tersebut melalui perilaku dalam kesehariannya. Siswa sebagai seorang individu akan berpikir bagaimana agar tujuan tercapai. Salah satu satu tujuan yang dicapai siswa adalah berkaitan dengan karirnya. Dengan kata lain, siswa memiliki self determination terkait masa depannya.

Self determination atau determinasi diri adalah kemampuan diri dalam mengidentifikasi dan mencapai tujuan berdasarkan pengetahuan dan penilaian individu terhadap dirinya sendiri (Field \& Hoffman, 1994, p. 164 dalam Field, Hoffman \& Posch. 1997). Jika dikaitkan dengan siswa, maka self determination siswa adalah kemampuan siswa dalam mencapai tujuannya sebagai pelajar yaitu keberhasilan secara akademik, pribadi sosial, dan karir. Jika siswa mampu berkembang dengan baik pada keempat aspek tersebut, maka dapat dikatakan siswa berhasil mencapai tujuannya.

Aspek karir memiliki kedudukan yang setara dengan perkembangannya dengan aspek akademik, pribadi, dan sosial. Hal ini didukung oleeh salah satu tujuan pendidikan dalam proses pembelajaran yang diterjemahkan dari makna mencerdaskan kehidupan bangsa yaitu siswa diharapkan mampu menentukan pilihan karirnya secara mandiri (ABKIN, 2007). Dengan kata lain, siswa diharapkan mampu mengambil keputusan yang disesuaikan dengan pilihan karir yang akan digelutinya.

Keputusan karir merupakan langkah siswa dalam mencapai tujuan masa depannya. Hal itu perlu disadari oleh siswa dalam proses pembelajarannya. Kesadaran siswa bahwa hidupnya memiliki sebuah tujuan merupakan sebuah proses. Tidak ada siswa bahkan individu manapun yang saat lahir langsung mengetahui tujuan atau apa yang hendak ia aktualisasikan dalam kehidupannya. Proses dalam kehidupan siswa dalam berbagai aspek membawanya pada pencapaian tujuan.

Terdapat tiga macam tanggapan siswa yang setelah melalui proses berespon pada tujuan yaitu pertama siswa yang melalui proses sadar tujuan apa yang akan dicapai; kedua, siswa yang melalui proses belum tentu atau sulit dalam mengenali tujuan hidup apa yang hendak dicapai; dan ketiga adalah siswa yang melalui proses sadar tujuan apa akan dicapai, namun dia tidak melakukan apa-apa untuk mencapainya.

Siswa menetapkan hati, artinya siswa mengambil sikap secara sadar terhadap karirnya. Sadar yang dimaksud adalah didorong oleh dorongan dari dalam dirinya. Dorongan dari dalam diri siswa atau yang biasa dikenal dengan motivasi intrinsik merupakan suatu faktor yang dapat menunjang keberhasilan.

Dalam usaha merealisasikan tanggapan siswa pada pencapaian tujuan, dibutuhkan suatu dorongan. Motivasi merupakan sebuah dorongan individu dalam berperilaku untuk mencapai tujuan. Seseorang dikatakan mencapai tujuan dapat dikatakan juga bahwa dirinya mencapai suatu prestasi. Oleh karena dorongan yang seseorang mampu mencapai prestasi disebut sebagai motivasi berprestasi (McClelland dalam Danim, 2004).

Sukadji (2001) menyatakan bahwa ciri-ciri individu yang memiliki motivasi berprestasi yang tinggi adalah: (a) selalu berusaha, tidak mudah menyerah dalam mencapai sukses maupun dalam berkompetisi, dengan menentukan sendiri standard bagi prestasinya; (b) secara umum tidak menampilkan hasil yang lebih baik pada tugas-tugas rutin, tetapi mereka biasanya menampilkan hasil yang lebih baik pada tugas-tugas khusus yang memiliki arti bagi mereka; (c) dalam melakukan sesuatu tidak didorong atau dipengaruhi oleh reward (hadiah atau uang); (d) cenderung mengambil risiko yang wajar (bertaraf sedang) dan diperhitungkan. Mereka tidak 
akan melakukan hal-hal yang dianggapnya terlalu mudah ataupun terlalu sulit; (e) mencoba memperoleh umpan balik dari perbuatannya; (f) mencermati lingkungan dan mencari kesempatan/peluang; (g) bergaul lebih untuk memperoleh pengalaman; (h) menyenangi situasi menantang, dimana mereka dapat memanfaatkan kemampuannya; (i) cenderung mencari cara-cara yang unik dalam menyelesaikan suatu masalah; (j) kreatif; (k) dalam bekerja atau belajar seakan-akan dikejar waktu.

Berdasarkan ciri yang dipaparkan, siswa yang memiliki motivasi untuk berprestasi adalah siswa tahu apa yang harus dilakukan, dan tahu apa yang menjadi pilihannya. Hal tersebut memberikan dampak pada pengambilan keputusannya karirnya.

Siswa SMA yang berada apa usia remaja, merupakan masa penting dari kehidupan seorang individu dalam memulai pengaturan diri terhadap penentuan pilihanpilihan. Masa yang dipenuhi dengan berbagai macam peran dan kondisi yang harus dipelajari remaja dalam waktu bersamaan. Masa remaja ditunjukan dengan masa penuh dengan tanggung jawab dan kemandirian untuk membawa diri sendiri berkembang, siap ke masa selanjutnya. Sikap individu pada masa remaja akan menentukan sikap individu dimasa selanjutnya.

Santrock (2003) menggambarkan remaja dihadapkan dengan situasi pengambilan keputusan tentang bagaimana menghadapi kondisi saat ini, perilaku seperti apa yang harus ditunjukkan agar diterima dalam pergaulan, tentang masa depan, teman-teman mana yang dipilih, apakah harus kuliah, apakah harus bekerja, dan seterusnya. Mann \& dkk (dalam Santrock, 2003) berpendapat bahwa remaja cenderung menghasilkan pilihan-pilihan yang mengutamakan kepuasan sesaaat, menguji situasi dengan perspektif yang terbatas, belum matang mengantisipasi akibat dari keputusan-keputusan, dan kurang mempertimbangkan kredibilitas sumbersumber. Feldmen (dalam Papalia, Olds, \& Feldmen, 2009) berpendapat bahwa remaja tergolong pribadi yang belum matang dalam beberapa hal, khususnya dalam cara berpikirnya. Dalam hal ini, terkait juga dengan cara berpikir remaja atau pilihan remaja terhadap aspek karir.

- Peneliti melakukan survey sebagai data pra penelitian terhadap siswa SMK. Peneliti menggunakan Daftar Cek Masalah (DCM). Pada aspek masa depan dan citacita, dari 162 siswa menunjukkan bahwa terdapat 8,02\% siswa mudah terpengaruh teman; $6,79 \%$ siswa sulit memilih pekerjaan; dan $11,11 \%$ siswa sulit mengambil keputusan. Hasil ini didukung dengan hasil survey yang dilakukan oleh Kurniawan (2011) bahwa 64,25\% siswa SMA/MA/SMK kelas III baik yang memiliki prestasi akademik baik dan sedang, belum memiliki pilihan profesi dan pekerjaan. Demikian juga dengan 52,3\% siswa-siswi belum memutuskan perguruan tinggi mana yang akan dipilih. Siswa-siswi tersebut menyatakan bahwa mereka belum memiliki keputusan.

Permasalahan yang muncul pada siswa berkaitan dengan aspek karirnya antara lain siswa kurang menyadari bahwa dirinya adalah individu yang sarat akan tujuan hidup; siswa belum menyadari bahwa dirinya perlu memiliki tekad untuk mencapai tujuannya; siswa kurang memiliki motivasi berprestasi yang tinggi dalam dirinya; siswa belum dapat memilih pilihan karirnya secara mandiri; siswa belum menyadari bahwa kebulatan tekad mampu mempengaruhi pilihan karirnya; belum adanya kesadaran bahwa tujuan hidupnya dan memiliki dorongan berprestasi yang tinggi mampu menuntunnya dalam menentukan pilihan karir.

Berdasarkan paparan dalam latar belakang yang telah disampaikan, dan masalah-masalah-masalah yang muncul berkaitan dengan aspek karir siswa, maka peneliti merumuskan masalah penelitian dengan berfokus pada bagaimana hubungan antara self determination dan motivasi berprestasi terhadap pengambilan keputusan karir siswa SMA. 


\subsection{Tujuan Penelitian}

Tujuan dalam penelitian ini adalah untuk memberikan gambaran dan menganalisa hubungan self determination dan motivasi berprestasi terhadap pengambilan keputusan karir siswa SMA.

Penelitian ini dlaksanakan untuk menjawab beberapa pertanyaan yaitu: 1) Bagaimana gambaran self determination siswa SMA?; 2) Bagaimana gambaran motivasi berprestasi siswa SMA?; 3) Bagaimana gambaran kemampuan pengambilan keputusan karir siswa SMA?; 4) Apakah terdapat hubungan antara self determination terhadap pengambilan keputusan karir siswa SMA; 5) Apakah terdapat hubungan antara motivasi berprestasi terhadap pengambilan keputusan karir siswa SMA; 6) Apakah terdapat hubungan antara self determination dan motivasi berprestasi dengan pengambilan keputusan karir siswa SMA

Penelitian ini berfokus pada aspek karir siswa SMA kelas XI. Peneliti memilih siswa SMA kelas XI dikarenakan masa SMA jika dikaitkan pada tahap perkembangan manusia, merupakan masa akhir dari remaja. Masa remaja yang penuh dengan tantangan dalam hal pilihan, pemenuhan tanggung jawab, pengembangan berbagai kemampuan, pengujian diri terhadap berbagai hal yang baru dan atau menimbulkan kesadaran terhadap pola pikir baru, dan lain sebagainya. Masa remaja akhir ini, individu mulai memiliki kesadaran akan untuk apa dia hidup, kemudian mencari tahu, dan mencoba bertindak untuk mencapainya. Siswa kelas XI SMA memiliki karakteristik yang telah memilih jurusan (IPA atau IPS), bingung terhadap tujuan setelah lulus SMA akan mengambil jurusan apa di perguruan tinggi, membutuhkan informasi karir, dan membutuhkan dukungan untuk penetapan pilihan.

\section{KAJIAN TEORITIS}

\subsection{Self determination}

Self determination dipaparkan sebagai usaha dalam menentukan tujuan dalam kehidupan sendiri. Self determination merupakan teori motivasi. Berfokus pada intrinsic motivation atau motivasi yang muncul dari dalam diri seseorang (Deci \& Ryan). Deci \& Ryan (dalam Field, Hoffman \& Posch. 1997) berdasarkan prespektif psikologi mendefinisikan self determination sebagai kapasitas seseorang untuk memilih dan memiliki beberapa pilihan untuk menentukan suatu tindakan.

Dapat dikatakan bahwa kebulatan tekad seseorang atau ketetapan hati seseorang pada suatu tujuan yang hendak dicapainya. Self determination adalah kemampuan diri dalam mengidentifikasi dan mencapai tujuan berdasarkan pengetahuan dan penilaian individu terhadap diri sendiri (Field \& Hoffman, 1994, p. 164 dalam Field, Hoffman \& Posch. 1997). Powers, dkk (dalam dalam Field, Hoffman \& Posch. 1997) berpendapat bahwa self determination merupakan sikap dan kemampuan individu yang dapat memfasilitasi dirinya dalam mengidentifikasi dan mencapai tujuan. Power (dalam dalam Field, Hoffman \& Posch. 1997) berpendapat bahwa self determination dapat direfleksikan sebagai penguasaan diri sendiri atau kontrol diri, berpartisipasi aktif dalam pembuatan keputusan, dan kemampuan memimpin diri sendiri untuk menggapai tujuan hidup pribadi yang bernilai.

Berdasarkan beberapa pengertian yang dipaparkan, self determination digambarkan atau terdiri dari beberapa komponen. Palmer dan Wehmeyer (2003) menyatakan bahwa komponen pemecahan masalah dan penentuan tujuan merupakan komponen yang penting dalam self determination. Kedua komponen tersebut perlu dikuasai oleh seseorang dari sejak anak-anak. Sedangkan Niemic dan Ryan (2009) mengungkapkan bahwa komponen self determination terdiri dari otonomi (autonomy), kompetensi (competence), dan relasi (relatedness). Deci dan Ryan melihat ketiga komponen itu sebagai tiga kebutuhan psikologis bawaan yang mendasari perilaku (dalam Schunk, Pintrich, Meece, 2012). Kebutuhan Otonomi mengacu pada kebutuhan untuk merasakan kontrol, bertindak sebagai agen/penyebab, atau memiliki otonomi dalam interaksi dengan lingkungan, atau suatu persepsi lokus kualitas internal dari sudut pandang persepsi 
penyebab (Ryan \& Deci, 2000 dalam Schunk, Pintrich, Meece, 2012). Individuindividu memiliki suatu kebutuhan psikologis pokok untuk mengalami perasaan otonomi dan perasaan kontrol. Otonomi berkaitan dengan keberadaan individu secara mandiri. Jika dikaitkan dengan pengambilan keputusan, individu mampu mengambil keputusan sendiri bagi dirinya.

Kompetensi digambarkan sebagai kemampuan yang dimiliki oleh seseorang dalam mendukung tindakan yang akan dilakukan dalam mencapai tujuan. Kebutuhan untuk memiliki kompetensi serupa dengan kebutuhan memiliki penguasaan terhadap lingkungan (White, 1959 dalam Schunk, Pintrich, Meece, 2012). Individu-individu perlu merasa dirinya kompeten dan bertingkah laku kompeten dalam interaksinya dengan individu lain, dalam mengerjakan tugas dan aktivitas, dan dalam konteks yang lebih besar. Sedangkan relatedness berkaitan dengan hubungan seseorang dengan orang lain. (Niemic dan Ryan, 2009). Kebutuhan keterkaitan (relatedness) mengacu pada kebutuhan untuk menjadi bagian dari suatu kelompok, atau kadang-kadang disebut sebagai kebutuhan kecocokan sosial (belongingness) (Schunk, Pintrich, Meece, 2012).

\subsection{Motivasi Berprestasi}

McClelland (dalam Danim, 2004) mendefinisikan motivasi berprestasi sebagai motivasi yang mendorong seseorang untuk mencapai keberhasilan dalam bersaing dengan suatu ukuran keunggulan (standard of excellence). Menurut Murray (dalam Winardi, 2004), motivasi berprestasi adalah suatu keinginan atau kecenderungan untuk mengatasi hambatan, melatih kekuatan, dan untuk berusaha melakukan sesuatu yang sulit dengan baik dan secepat mungkin. Sementara itu Atkinson (dalam Sukmadinata, 2005) menyatakan bahwa motivasi berprestasi individu didasarkan atas dua hal, yaitu tendensi untuk meraih sukses dan tendensi untuk menghindari kegagalan. Individu yang memiliki motivasi berprestasi tinggi berarti ia memiliki motivasi untuk meraih sukses yang lebih kuat daripada motivasi untuk menghindari kegagalan, begitu pula sebaliknya.

Dari uraian mengenai motivasi berprestasi tersebut, dapat disimpulkan bahwa motivasi berprestasi adalah usaha yang dilakukan individu untuk mempertahankan kemampuan pribadi setinggi mungkin, untuk mengatasi rintangan-rintangan, dan bertujuan untuk berhasil dalam kompetisi dalam suatu ukuran keunggulan. Ukuran keunggulan dapat berupa prestasi sendiri sebelumnya atau dapat pula prestasi orang lain.

McClelland (dalam Danim, 2004) mengemukakan beberapa ciri individu yang memiliki motivasi berprestasi adalah sebagai berikut. 1) Berani mengambil resiko secara moderat. Individu dengan motivasi berprestasi tinggi cenderung memilih tugas dengan tingkat kesulitan menengah (moderate task difficulty), sementara individu dengan motivasi berprestasi rendah cenderung memilih tugas dengan tingkat kesulitan yang sangat tinggi atau rendah. Banyak studi empiris menunjukkan bahwa subjek dengan kebutuhan berprestasi tinggi lebih memilih tugas dengan tingkat kesulitan menengah, karena individu berkesempatan untuk membuktikan bahwa ia mampu melakukan sesuatu dengan lebih baik. McClelland mengatakan bahwa pemilihan tingkat kesulitan tugas berhubungan dengan seberapa besar usaha yang dilakukan oleh individu untuk memperoleh kesuksesan. Tugas yang mudah dapat diselesaikan oleh semua orang, sehingga individu tidak mengetahui seberapa besar usaha yang telah mereka lakukan untuk mencapai kesuksesan. Tugas sulit membuat individu tidak dapat mengetahui usaha yang sudah dihasilkan karena betapapun besar usaha yang telah mereka lakukan, namun mereka mengalami kegagalan. 2) Ketahanan atau ketekunan (persistence) dalam mengerjakan tugas. Individu dengan motivasi berprestasi tinggi akan lebih bertahan atau tekun dalam mengerjakan berbagai tugas, tidak mudah menyerah ketika mengalami kegagalan dan cenderung untuk terus mencoba menyelesaikan tugas, sementara individu dengan motivasi berprestasi rendah cenderung memiliki ketekunan yang rendah. Ketekunan individu dengan motivasi 
berprestasi rendah terbatas pada rasa takut akan kegagalan dan menghindari tugas dengan kesulitan menengah. 3). Harapan terhadap umpan balik (immediate feedback). Individu dengan motivasi berprestasi tinggi selalu mengharapkan umpan balik (feedback) atau tugas yang sudah dilakukan, bersifat konkret atau nyata mengenai seberapa baik hasil kerja yang telah dilakukan. Individu dengan motivasi berprestasi rendah tidak mengharapkan umpan balik atas tugas yang sudah dilakukan. Bagi individu dengan motivasi berprestasi tinggi, umpan balik yang bersifat materi seperti uang, bukan merupakan pendorong untuk melakukan sesuatu dengan lebih baik, namun digunakan sebagai pengukur keberhasilan. 4). Memiliki tanggung jawab pribadi terhadap kinerjanya. Individu dengan motivasi berprestasi tinggi memiliki tanggung jawab pribadi atas pekerjaan yang dilakukan. 5) Kemampuan dalam melakukan inovasi (innovativeness). Inovatif dapat diartikan mampu melakukan sesuatu lebih baik dengan cara berbeda dari biasanya. Individu dengan motivasi berprestasi tinggi akan menyelesaikan tugas dengan lebih baik, menyelesaikan tugas dengan cara berbeda dari biasanya, menghindari hal-hal rutin, aktif mencari informasi untuk menemukan cara yang lebih baik dalam melakukan sesuatu, serta cenderung menyukai hal-hal yang sifatnya menantang daripada individu yang memiliki motivasi berprestasi rendah.

\subsection{Kemampuan Pengambilan Keputusan Karir}

Proses pengambilan keputusan diawali dengan suatu keinginan akan perubahan, perasaan akan ketidaknyamanan, dan pencapaian akan sesuatu yang diharapkan. Untuk mencapai harapan tersebut, maka individu akan bergerak untuk melakukan pengumpulan informasi yang direalisasikan berdasarkan ide, perasaan, dan pengalaman waktu lalu. Nilai, kejadian, perasaan, dan harapan merupakan hal yang terintegral dalam diri individu sehingga mampu membuat perbedaan antara hal apa yang penting dan tidak. Sehingga berdasarkan pembedaan yang jelas mampu menentukan suatu alternatif pilihan yang menurut individu benar dan tepat sebagai suatu keputusan (Paolucci et. al, 1977).

Pengambilan keputusan dipandang sebagai proses pemberian alasan (reasoning) atau merupakan proses emosional untuk memunculkan pemikiran atau keyakinan yang rasional atau irasional terhadap suatu hal, didasarkan pada asumsi yang eksplisit atau jelas atau asumsi terselebung (Steinberg, 2009). Pengambilan keputusan yang baik menurut Stanovich (2010) adalah proses pengambilan tindakan terukur secara rasional, hal apa yang harus dilakukan dengan sumber (secara fisik maupun mental) yang tersedia baik bagi si individu.

Pengambilan keputusan karir merupakan sebuah proses dalam memilih sebuah pekerjaan (Zunker, 1994 dalam Rowland, 2004). Brown \& Brooks (dalam Rowland, 2004) mendefinisikan pengambilan keputusan karir sebagai sebuah proses pemikiran seseorang dalam mengintegrasikan atau menggabungkan pengetahuan tentang dirinya dengan pengetahuan suatu pekerjaan untuk membuat pilihan berkaitan dengan karir.

Cohen (2003) menggambarkan empat tahapan yang perlu dilalui melalui teknik eksistensial agar seseorang dapat mengambil keputusan yang benar. Keempat tahapan tersebut adalah; 1) responsibility stage. Tahap dimana kesadaran akan kebebasan dan tanggung jawab berperan. Berdasarkan perspektif eksistensial, tanggung jawab serupa dengan kebebasan; 2) evalution stage. Tahap dimana individu mengevaluasi semua pilihan karir yang muncul memberikan makna bagi kehidupannya. Pada tahap ini terdapat pencarian akan makna dan pencarian terhadap keaslian diri; 3) action stage. Tahap dimana individu menerapkan pilihan karimya pada suatu pekerjaan yang nyata; dan 4) re-evaluation stage. Tahap dimana individu mengevaluasi ulang pilihan karir yang telah diambil berdasarkan pengalaman kerja yang telah dilaluinya.

Pengambilan keputusan dapat diartikan sebagai sebuah proses dari membuat pilihan-pilihan berdasarkan alternatif-alternatif kemungkinan (Evans dkk., 2002). Furby \& Beyth-Marom dalam 
penelitiannya terhadap remaja yang berada dalam penjara menyatakan bahwa model paling efektif untuk melatihkan keterampilan pengambilan keputusan adalah proses yang dikembangkan oleh model normatif. Proses pengambilan keputusan dengan model normatif memiliki langkahlangkah: 1) mengidentifikasi kemungkinan pilihan-pilihan; 2) mengidentifikasi berbagai konsekuensi yang dapat mengikuti setiap pilihan yang muncul; 3) mengevaluasi setiap sifat yang diingini dari setiap konsekuensi; 4) menafsir setiap kemungkinan dari setiap konsekuensi; dan 5) menentukan pilihan dengan menggunakan aturan keputusan (Furby \& Beyth-Marom (1992) dalam Evans dkk., 2002).

\section{METODE PENELITIAN}

Populasi dari penelitian ini adalah siswa kelas XI dari lima SMA Swasta. Salah satu sekolah swasta dijadikan sebagai sampel uji coba, sedangkan keempat sekolah lainnya merupakan sampel penelitian. Sampel dalam penelitian ini berjumlah 410 siswa.

Variabel yang akan diteliti terdiri dari tiga variabel, yaitu 2 variabel bebas dan 1 variabel terikat. Kedua variabel bebas yang dimaksud adalah variable self determination dan motivasi berprestasi; dan 1 variabel terikat yaitu pengambilan keputusan karir. Berdasarkan teori yang diungkapan oleh Niemic \& Ryan, variabel Self determination dijabarkan sebagai kemampuan diri dalam mengidentifikasi keinginan yang berkaitan dengan otonomi, kompetensi, dan relasi dalam rangka mencapai tujuan yang ditetapkannya (Niemic dan Ryan, 2009; deCharms, 1969, Deci \& Ryan, 1985, 200 dalam Johnston \& Finney, 2010). Otonomi berkaitan dengan kebebasan individu untuk memilih dan penguasaan dia terhadap dirinya sendiri. Kompetensi berkaitan dengan pengusaan atau kemampun individu dan pertanggungjawaban dalam tugas yang dihadapinya. Sedangkan relasi berkaitan dengan hubungan indvidu dengan lingkungan sekolah, keluarga, dan teman sebaya. Berdasarkan teori McClelland, motivasi berprestasi dijelaskan sebagai usaha siswa untuk mencapai tujuan dengan cara berani mengambil resiko secara moderat, memiliki ketekunan dalam mengerjakan tugas, memiliki harapan terhadap umpan balik, memiliki tanggung jawab terhadap kinerja, dan memiliki kemampuan dalam melakukan inovasi (McClelland dalam Danim, 2004).

Pengambilan keputusan karir yang didasarkan pada penjelasan Brown \& Brooks merupakan kemampuan individu terkait proses penilaian dan pemikirannya dalam mengintegrasikan atau menggabungkan pengetahuan tentang dirinya dengan pengetahuan suatu pekerjaan untuk membuat pilihan berkaitan dengan karir (dalam Rowland, 2004). Pemahaman tentang diri sendiri terkait memahami kekuatan dan kelemahan diri dan bagaimana mengidentifikasi perilaku dalam pemilihan karir, dan kesadaran individu terhadap tujuan yang ingin dicapai. Sedangkan pemahaman tentang pekerjaan berkaitan dengan informasi macam pekerjaan atau karir dan informasi aspek-aspek pekerjaan.

Penelitian ini menggunakan metode penelitian kuantitatif dengan jenis penelitian korelasional ganda. Jenis korelasional dalam penelitian ini bertujuan untuk melihat hubungan antara dua independent variable (self determination dan motivasi berprestasi) dengan 1 dependent variable (kemampuan pengambilan keputusan karir).

Dalam proses pengumpulan data, peneliti menggunakan inventori berbentuk skala penilaian. Inventori berbentuk skala penilaian ini akan mengukur variabel self determination, motivasi berprestasi, dan pengambilan keputusan karir. Peneliti akan mengembangkan inventori sendiri terkait dengan ketiga variabel. Peneliti mengembangkan inventori berdasarkan pada jabaran variabel yang terdapat pada bagian variabel penelitian. Pilihan jawaban dalam skala penilaian terdiri dari 4 pilihan jawaban yaitu pilihan selalu (SS), sangat sesuai (S), kurang sesuai (KS), dan tidak sesuai (TS).

Peneliti melakukan telaah validitas dan realibilitas terhadap 60 sampel uji coba. Uji validitas instrument dilakukan dengan menggunakan perhitungan korelasi product moment dan uji realibilitas dengan menggunakan alpha cronbach, yang dianalisis dengan komputer program SPSS 
versi 17. Uji validitas terhadap instrument variabel self determination diperoleh 63 pernyataan valid dari 71 pernyataan dengan reliabilitas sebesar 0,911. Pada instrumen variabel motivasi berprestasi diperoleh 65 pernyataan valid dari 80 pernyataan dengan reliabilitas sebesar 0, 939. Pada variabel kemampuan pengambilan keputusan karir diperoleh 40 pernyataan valid dari 49 pernyataan dengan reliabilitas sebesar 0 , 926.

Teknik analisis data dilakukan dengan menggunakan teknik statistik analisis deskriptif dan teknik analisis korelasi product moment untuk menganalisis hubungan antara variabel $\mathrm{X} 1$ terhadap $\mathrm{Y}$, dan variabel X2 terhadap Y. Sedangkan untuk mengetahui hubungan antara $\mathrm{X} 1$ dan $\mathrm{X} 2$ dengan $\mathrm{Y}$, peneliti menggunakan analisis korelasi ganda. Data variabel dalam penelitian ini dikategorikan ke dalam tiga kategori yaitu tinggi, sedang, dan rendah.

\section{HASIL DAN PEMBAHASAN}

\subsection{Hasil analisis deskriptif}

$\underline{\text { Self Determination }}$

Hasil analisis data dari variabel self determination adalah sebagai berikut.

Tabel 1: Distribusi Skor Rata-Rata Tiap Komponen Variabel Self Determination

\begin{tabular}{llll}
\hline Komponen & $\begin{array}{l}\text { Jumlah } \\
\text { item }\end{array}$ & $\begin{array}{l}\text { Total } \\
\text { Skor }\end{array}$ & $\begin{array}{l}\text { Rata- } \\
\text { Rata }\end{array}$ \\
\hline Otonomi & 11 & 11864 & 1078,5 \\
Kompetensi & 16 & 17233 & 1077,0 \\
Relasi & 20 & 21844 & 1092,2 \\
\hline Total & $\mathbf{4 7}$ & $\mathbf{5 0 9 4 1}$ & $\mathbf{1 0 8 3 , 9}$ \\
\hline
\end{tabular}

Berdasarkan tabel 1, diperoleh data yang menunjukkan bahwa komponen otonomi memiliki total skor sebesar 11864 dengan rata-rata 1078,5; untuk komponen kompetensi memiliki total skor sebesar 17233 dengan rata-rata 1077,0; untuk komponen relasi memiliki total skor sebesar 21844 dengan rata-rata 1092,2. Berdasarkan rata-rata keseluruhan item yang diperoleh sebesar 1083,9, maka dapat diperoleh komponen yang memiliki skor diatas ratarata adalah komponen relasi. Sedangkan komponen yang memiliki skor dibawah ratarata adalah komponen otonomi dan kompetensi.

Variabel self determination dibagi ke dalam tiga klasifikasi yaitu tinggi, sedang, dan rendah. Perhitungan klasifikasi ini menggunakan rentang skor. Rentang skor diperoleh dari hasil pengurangan skor tertinggi dengan skor terendah. Skor tertinggi didapatkan dari hasil perkalian antara jumlah pernyataan yang valid dikalikan lima (47 x $4=188)$, sedangkan skor terendah didapatkan dari hasil perkalian antara jumlah pernyataan valid dikalikan satu (47 x $1=47)$. Kemudian hasil pengurangan skor dibagi tiga. Rentang skor variabel keberadaan psikologis siswa adalah sebesar 141, kemudian dibagi tiga hasilnya menjadi 47. Klasifikasi variabel self determination siswa dapat dilihat pada tabel 2 sebagai berikut.

Tabel 2: Klasifikasi Variabel Self Determination

\begin{tabular}{|c|c|c|c|}
\hline $\begin{array}{c}\text { Rentang } \\
\text { skor }\end{array}$ & $\begin{array}{c}\text { Klasifi- } \\
\text { kasi }\end{array}$ & Frekuensi & $\begin{array}{c}\text { Persen- } \\
\text { tase } \\
(\%)\end{array}$ \\
\hline $\begin{array}{c}141- \\
188\end{array}$ & Tinggi & 141 & 34,40 \\
\hline $94-140$ & Sedang & 189 & 46,1 \\
\hline \multirow[t]{2}{*}{$47-93$} & Rendah & 80 & 19,51 \\
\hline & Total & 410 & 100 \\
\hline
\end{tabular}

Berdasarkan data tabel 2 dapat dilihat bahwa gambaran self determination siswa kelas XI berada pada klasifikasi sedang yaitu sebesar 46,1\%.

\section{$\underline{\text { Motivasi Berprestasi }}$}

Hasil analisis data dari variabel motivasi berprestasi. 
Tabel 3: Distribusi Skor Rata-Rata Tiap Komponen Variabel Motivasi Berprestasi

\begin{tabular}{|c|c|c|c|}
\hline Komponen & $\begin{array}{l}\text { Jum- } \\
\text { lah } \\
\text { item }\end{array}$ & $\begin{array}{l}\text { Total } \\
\text { Skor }\end{array}$ & $\begin{array}{l}\text { Rata- } \\
\text { Rata }\end{array}$ \\
\hline $\begin{array}{l}\text { Berani } \\
\text { mengambil } \\
\text { resiko secara } \\
\text { moderat } \\
\text { (tingkat } \\
\text { kesulitan } \\
\text { menengah) } \\
\text { dalam } \\
\text { pemilihan } \\
\text { tugas. }\end{array}$ & 11 & 12495 & 1136 \\
\hline $\begin{array}{l}\text { Ketahanan atau } \\
\text { ketekunan } \\
\text { (persistence) } \\
\text { dalam } \\
\text { mengerjakan } \\
\text { tugas. }\end{array}$ & 14 & 15751 & 1125,1 \\
\hline $\begin{array}{l}\text { Harapan } \\
\text { terhadap umpan } \\
\text { balik } \\
\text { (Immediate } \\
\text { feedback). }\end{array}$ & 9 & 10964 & 1218,2 \\
\hline $\begin{array}{l}\text { Memiliki } \\
\text { tanggung jawab } \\
\text { pribadi. }\end{array}$ & 14 & 17383 & 1241,6 \\
\hline $\begin{array}{l}\text { Kemampuan } \\
\text { dalam } \\
\text { melakukan } \\
\text { inovasi/kreatif/u } \\
\text { nggul } \\
\text { (Innovative- } \\
\text { ness). }\end{array}$ & 9 & 10317 & 1146,3 \\
\hline Total & 57 & 66910 & 1173,9 \\
\hline
\end{tabular}

mengerjakan tugas memiliki total skor sebesar 15751 dengan rata-rata 1125,1 ; untuk komponen harapan terhadap umpan balik (Immediate feedback) memiliki total skor sebesar 10964 dengan rata-rata 1218,2; dan untuk kemampuan dalam melakukan inovasi/ kreatif/ unggul (Innovativeness) memiliki total skor sebesar 10317 dengan rata-rata 1146,3. Berdasarkan rata-rata keseluruhan item yang diperoleh sebesar 1173,9, maka dapat diperoleh komponen yang memiliki skor diatas rata-rata adalah komponen memiliki tanggung jawab pribadi dan harapan terhadap umpan balik. Sedangkan komponen yang memiliki skor dibawah rata-rata adalah komponen kemampuan dalam melakukan inovasi/kreatif/unggul, berani mengambil resiko secara moderat (tingkat kesulitan menengah) dalam pemilihan tugas, dan ketahanan atau ketekunan (persistence) dalam mengerjakan tugas.

Variabel motivasi berprestasi dibagi ke dalam tiga klasifikasi yaitu tinggi, sedang, dan rendah. Perhitungan klasifikasi ini menggunakan rentang skor. Rentang skor diperoleh dari hasil pengurangan skor tertinggi dengan skor terendah. Skor tertinggi didapatkan dari hasil perkalian antara jumlah pernyataan yang valid dikalikan lima (57 x $4=228)$, sedangkan skor terendah didapatkan dari hasil perkalian antara jumlah pernyataan valid dikalikan satu $(57$ x $1=57)$. Kemudian hasil pengurangan skor dibagi tiga. Rentang skor variabel keberadaan psikologis siswa adalah sebesar 171, kemudian dibagi tiga hasilnya menjadi 57. Klasifikasi variabel motivasi berprestasi siswa dapat dilihat pada tabel 4 sebagai berikut.
Berdasarkan tabel 3, diperoleh data yang menunjukkan bahwa komponen berani mengambil resiko secara moderat (tingkat kesulitan menengah) dalam pemilihan tugas memiliki total skor sebesar 12495 dengan rata-rata 1136; untuk komponen ketahanan atau ketekunan (persistence) dalam 
Tabel 4: Klasifikasi Variabel Motivasi Berprestasi

\begin{tabular}{cccc}
\hline $\begin{array}{c}\text { Rentang } \\
\text { skor }\end{array}$ & $\begin{array}{c}\text { Klasifik } \\
\text { si }\end{array}$ & $\begin{array}{c}\text { Freku } \\
\text { ensi }\end{array}$ & Persentase \\
\hline $171-228$ & Tinggi & 156 & 38,05 \\
$114-170$ & Sedang & 251 & 61,22 \\
$57-113$ & Rendah & 3 & 0,73 \\
\hline & Total & $\mathbf{4 1 0}$ & $\mathbf{1 0 0}$ \\
\hline
\end{tabular}

Berdasarkan data tabel 4 dapat dilihat bahwa gambaran motivasi berprestasi siswa kelas XI berada pada klasifikasi sedang yaitu sebesar $61,22 \%$.

$\underline{\text { Kemampuan Pengambilan Keputusan Karir }}$

Hasil analisis data dari variabel motivasi berprestasi adalah sebagai berikut.

Tabel 5: Distribusi Skor Rata-Rata Tiap Komponen Variabel Kemampuan

\begin{tabular}{lccc}
\hline Komponen & $\begin{array}{c}\text { Jumlah } \\
\text { item }\end{array}$ & $\begin{array}{c}\text { Total } \\
\text { Skor }\end{array}$ & $\begin{array}{c}\text { Rata- } \\
\text { Rata }\end{array}$ \\
\hline $\begin{array}{l}\text { Pemahaman } \\
\text { diri sendiri }\end{array}$ & 26 & 29116 & 1119,8 \\
$\begin{array}{l}\text { Pemahaman } \\
\text { tentang karir }\end{array}$ & 14 & 15368 & 1097,7 \\
\hline Total & $\mathbf{4 0}$ & $\mathbf{4 4 4 8 4}$ & $\mathbf{1 1 1 2 , 1}$ \\
\hline
\end{tabular}

Berdasarkan tabel 5, diperoleh data yang menunjukkan bahwa komponen pemahaman diri sendiri memiliki total skor sebesar 29116 dengan rata-rata 1119,8; dan untuk komponen pemahaman tentang karir memiliki total skor sebesar 15368 dengan rata-rata 1097,7. Berdasarkan rata-rata keseluruhan item yang diperoleh sebesar 1112,1, maka dapat diperoleh komponen yang memiliki skor diatas rata-rata adalah komponen pemahaman terhadap diri sendiri. Sedangkan komponen yang memiliki skor dibawah rata-rata adalah komponen pemahaman siswa tentang karir.

Variabel kemampuan pengambilan keputusan pribadi dibagi ke dalam tiga klasifikasi yaitu tinggi, sedang, dan rendah. Perhitungan klasifikasi ini menggunakan rentang skor. Rentang skor diperoleh dari hasil pengurangan skor tertinggi dengan skor terendah. Skor tertinggi didapatkan dari hasil perkalian antara jumlah pernyataan yang valid dikalikan lima (40 x $4=160)$, sedangkan skor terendah didapatkan dari hasil perkalian antara jumlah pernyataan valid dikalikan satu (40 x $1=40)$. Kemudian hasil pengurangan skor dibagi tiga. Rentang skor variabel keberadaan psikologis siswa adalah sebesar 120, kemudian dibagi tiga hasilnya menjadi 40. Klasifikasi variabel kemampuan pengambilan keputusan karir siswa dapat dilihat pada tabel 6 sebagai berikut.

Tabel 6: Klasifikasi Variabel Kemampuan Pengambilan Keputusan Karir

\begin{tabular}{cccc}
\hline $\begin{array}{c}\text { Rentang } \\
\text { skor }\end{array}$ & $\begin{array}{c}\text { Klasifi- } \\
\text { kasi }\end{array}$ & $\begin{array}{c}\text { Frekue- } \\
\text { nsi }\end{array}$ & $\begin{array}{c}\text { Persen- } \\
\text { tase(\%) }\end{array}$ \\
\hline $120-160$ & Tinggi & 179 & 43,66 \\
$80-119$ & Sedang & 141 & 34,39 \\
$40-79$ & Rendah & 90 & 21,95 \\
\hline & Total & $\mathbf{4 1 0}$ & $\mathbf{1 0 0}$ \\
\hline
\end{tabular}

Berdasarkan data tabel 6 dapat dilihat bahwa gambaran kemampuan pengambilan keputusan karir siswa kelas XI berada pada klasifikasi tinggi yaitu $43,66 \%$.

\subsection{Hasil Analisis Korelatif}

Peneliti melakukan analisis korelatif untuk melihat: 1) keterhubungan antara variabel self determination dengan kemampuan pengambilan keputusan karir; 2) keterhubungan antara variabel motivasi berprestasi dengan kemampuan pengambilan keputusan karir; dan 3) keterhubungan antara variabel self determination dengan motivasi berprestasi terhadap kemampuan pengambilan keputusan karir. Gambaran hasil korelasi adalah sebagai berikut. 
Tabel 7. Hasil Korelasi

\begin{tabular}{rlrrr}
\hline & & \multicolumn{1}{c}{ SDT } & \multicolumn{1}{c}{ PKK } \\
\hline SDT & Pearson & 1 &, 009 & \multicolumn{1}{c}{, $883^{* *}$} \\
& Correlation & &, 864 &, 000 \\
& Sig. (2-tailed) & & 410 & 410 \\
& N & 410 & 410 &,- 011 \\
\hline MB & Pearson &, 009 & 1 &, 822 \\
& Correlation & & & 410 \\
& Sig. (2-tailed) &, 864 & & 1 \\
& N & 410 & 410 & 4 \\
\hline PKK & Pearson &, $883^{* *}$ &,- 011 & \\
& Correlation & & & \\
& Sig. (2-tailed) &, 000 &, 822 & \\
& N & 410 & 410 & 410
\end{tabular}

(Keterangan: SDT $=$ Self Determination; $\mathrm{MB}=$ Motivasi Berprestasi; $\mathrm{PKK}=$ Pengambilan Keputusan Karir)

Hasil perhitungan statistik variabel self determination dengan kemampuan pengambilan keputusan karir menghasilkan korelasi sebesar 0,883 dengan signifikan sebesar 0,00 ( pada level signifikansi 0,05). Dikarenakan $P$-value $=0,00$ lebih kecil dari $\alpha=0,05$, maka hasil ini menunjukkan terdapat hubungan yang signifikan dan positif antara variabel self determination dengan kemampuan pengambilan keputusan karir. Hasil perhitungan statistik variabel motivasi berprestasi dengan kemampuan pengambilan keputusan karir menghasilkan korelasi sebesar -0,011 dengan signifikan sebesar 0,411 pada level signifikansi 0,05. Dikarenakan $P$-value $=0,411$ lebih besar dari $\alpha=0,05$, maka hasil ini menunjukkan tidak adanya hubungan yang signifikan antara variabel motivasi berprestasi dengan kemampuan pengambilan keputusan karir. Untuk gambaran korelasi antara variabel self determination, dan motivasi berprestasi terhadap kemampuan pengambilan keputusan karir tergambar sebagai berikut. Hasil korelasi antara variabel self determination dengan motivasi berprestasi terhadap kemampuan pengambilan keputusan karir menghasilkan korelasi sebesar 0,780 dengan signifikan sebesar 0,00 pada level signifikansi 0,05 . Dikarenakan $P$ value $=0,00$ lebih besar dari $\alpha=0,05$, hasil ini menunjukkan bahwa terdapat korelasi positif yang signifikan antara variabel self determination dengan motivasi berprestasi terhadap kemampuan pengambilan keputusan karir. Variabel self determination dan motivasi berprestasi memberikan kontribusi sebesar $78 \%$ (nilai $\mathrm{R}^{2}=\mathrm{R}$ Squere $\mathrm{x} 100 \%$ ) dengan variabel kemampuan pengambilan keputusan karir.

\subsection{Pembahasan}

Gambaran variabel self determination, komponen terendah yaitu otonomi dan kompetensi. Otonomi terkait dengan keberadaan siswa secara mandiri dapat dipercaya untuk dapat membuat plihan sendiri. Siswa cenderung bukan tidak dapat membuat pilihan, namun lebih kepada tidak memiliki keberanian atau kurangnya kepercayaan diri dalam membuat atau menentukan pilihan. Hal ini sesuai seperti yang Santrock gambarkan bahwa remaja kesulitan dalam menentukan posisi otonominya khususnya dalam pengambilan keputusan. (Santrock, 2003). Keterlibatan orang dewasa khususnya orang tua masih mengambil peran lebih besar untuk membuat keputusan bagi serang remaja. Kondisi ini menggambarkan remaja Indonesia (budaya timur) bahwa remaja masih dianggap "sebelah mata" dalam mengambil keputusan. Dengan kata lain, orang tua belum percaya sepenuhnya kalau remaja, anaknya, siswa kelas XI telah mampu membuat pilihan atas masa depannya. Kondisi ini bertentangan dengan tujuan bimbingan karir yang ditetapkan oleh ABKIN (2007) yaitu siswa mampu mandiri, dan mampu membuat atau menentukan tujuan secara mandiri.

Pada variabel motivasi berprestasi, komponen terendah adalah ketahanan atau ketekunan dalam mengerjakan tugas. Seperti halnya gambaran bahwa generasi saat ini disebut sebagai generasi "Y", salah satu ciri generasi "Y" adalah kurang menyukai tugas yang sulit, menghindari tantangan, cari aman, cari 'gampangnya" saja, dan kurnag menyukai tugas yang menuntut tanggung jawab besar. Hal ini dapat menggambarkan atau mengidikasikan kurangnya motivasi pada siswa untuk melakukan sesuatu atau menekuni suatu hal untuk pengembangan 
dirinya. Siswa cenderung menggunakan cara "instant".

$$
\text { Pada variabel kemampuan }
$$

pengambilan keputusan karir, komponen terendah adalah pemahaman tentang karir. Jika siswa tidak mendapatkan pemahaman karir yang benar atau baik, maka akan menjadi salah satu faktor penyebab siswa tidak dapat menentukan karir. Dengan kata lain, siswa tidak dapat mengambil keputusan karir. Hal ini sejalan dengan yang diungkapan oleh Gati et al. (dalam Fouad, et al., 2009) bahwa individu tidak dapat membuat keputusan karir disebabkan oleh tiga hal yaitu kurangnya kesiapan, kurangnya informasi karir, dan adanya ketidakonsistenan informasi karir. Salah satunya penyebab kondisi ini muncul adalah layanan bimbingan karir disekolah yang belum maksimal memberikan informasi yang dibutuhkan oleh siswa. Kondisi ini sejalan dengan yang digambarkan oleh Fisher dan Griggs (1995; dalam Rowland 2004) bahwa remaja akan mengalami kerugian saat perkembangan karir mereka yang disebabkan oleh keterbatasan sumber informasi terkait dengan karir yang mereka inginkan. Hal ini dapat menimbulkan siswa mengalami kebingungan yang membawa mereka sulit mengambil keputusan karir. Salah satu penanganan yang bisa dilakukan adalah dengan memberikan bimbingan atau metode intervensi baik kelompok maupun secara individual. Salah satunya adalah refleksi diri terkait dengan karir. Hal ini sejalan dengan yang diajukan oleh Brown \& Krane (2000, dalam Fouad, et al., 2009) menggambarkan bahwa salah satu komponen yang dapat mendukung siswa memiliki kemampuan pengambilan keputusan karir yang baik adalah dengan memiliki written exercise, yaitu mengajak siswa untuk selalu menuliskan atau menuangkan pemikiran, perasaan, dan refleksi mereka terkait dengan perkembangan karir atau terkait pilihan karir yang mereka ketahui. Dengan cara ini, siswa semakin sadar dan mampu membandingkan pekerjaan mana yang cocok dengan pribadi mereka dimasa depan.

Hasil korelasi antara self determination dan kemampuan pengambilan keputusan karir menunjukkan hubungan positif yang signifikan. Hal ini menunjukkan bahwa semakin tinggi self determination siswa, maka akan semakin baik dalam mengambil keputusan karir. Saat siswa mengerti dan dapat menentukan tujuan dalam hidupnya, maka dia akan menyusun berbagai pilihan yang sesuai dengan potensi dirinya. Dengan kata lain siswa akan mengumpulkan informasi yang sesuai, mengkonsultasikan kepada orang lain seperti orang tua, guru BK, dan teman sebaya, dan kemudian mengambil keputusan untuk masa depannya.

Hal ini sejalan dengan Wehmeyer (2003 dalam Benitez et. al., 2005) paparkan bahwa seseorang yang memiliki keterampilan self determination yang baik yaitu mampu merumuskan goal setting, dia dapat membuat keputusan karir yang tepat untuk dirinya. Selain itu, seperti yang diungkapkan oleh Deci \& Ryan (dalam Schunk, Pintrich, \& Meege, 2012) bahwa saat individu mengembangkan self determination yang menuntut individu menerima kekuatan dan keterbatasan diri mereka dan mengetahui berbagai kekuatan yang bertindak atas dirinya, maka mereka dapat menentukan pilihan dan mampu membuat keputusan untuk memenuhi kebutuhannya. Dalam hal ini adalah kebutuhan karir.

Hasil korelasi antara motivasi berprestasi dan kemampuan pengambilan keputusan karir menunjukkan tidak adanya hubungan yang signifikan. Seseorang yang memiliki dorongan kuat untuk berprestasi, tidak menunjukkan bahwa dia membutuhkan kemampuan pengambilan keputusan. Menurut Murray (dalam Winardi, 2004), motivasi berprestasi adalah suatu keinginan atau kecenderungan untuk mengatasi hambatan, melatih kekuatan, dan untuk berusaha melakukan sesuatu yang sulit dengan baik dan secepat mungkin. Sementara itu Atkinson (dalam Sukmadinata, 2005) menyatakan bahwa motivasi berprestasi individu didasarkan atas dua hal, yaitu tendensi untuk meraih sukses dan tendensi untuk menghindari kegagalan. Kedua pendapat ini menggambarkan bahwa motivasi berprestasi merupakan hal yang berpusat kepada hasil. Hal ini bertolak belakang dengan kemampuan pengambilan 
keputusan karir. Kemampuan pengambilan keputusan merupakan sebuah hal atau kondisi yang berfokus pada proses.

Hasil korelasi antara self determination dan motivasi berprestasi terhadap kemampuan pengambilan keputusan karir menunjukkan adanya hubungan kuat yang positif dan signifikan. Berdasarkan hasil ini dapat dikatakan bahwa semakin tinggi self determination dan motivasi berprestasi pada diri siswa, maka akan semakin baik kemampuan siswa dalam mengambil keputusan karir. Saat siswa memiliki kebebasan dalam mengungkapkan pilihan, memiliki keinginan atau dorongan untuk menguasai hal yang diperlukan dalam karirnya, memiliki kemampuan interaksi sosial yang baik, dan didukung dengan dorongan untuk berprestasi, maka siswa mampu menentukan pilihan atau dengan kata lain dapat membuat keputusan karir yang baik. Hal ini sesuai dengan yang dipaparkan oleh Super, et. al, 1957; Gottfredson, 1981; dalam Rowland, 2004) bahwa pengambilan keputusan karir untuk usia remaja membutuhkan level pemahaman karir yang mapan, yaitu tampak dari sikap dan kompetensi yang dimiliki. Kontribusi self determination dan motivasi berprestasi terhadap kemampuan pengmabilan keputusan karir adalah sebesar 78\%. Hal ini menggambarkan bahwa siswa mampu membuat keputusan karir perlu didasari dengan keyakinan dan dorongan yang kuat dari dalam dirinya untuk berhasil.

\section{SIMPULAN DAN SARAN}

Beberapa kesimpulan yang ditemukan dalam penelitian mengenai hubungan antara self determination dan motivasi berprestasi terhadap kemampuan pengambilan keputusan siswa SMA kelas XI adalah sebagai berikut:

1. Self determination siswa kelas XI berada pada kategori sedang yaitu $46,1 \%$.

2. Motivasi berprestasi siswa kelas XI berada pada kategori sedang yaitu 61, $22 \%$

3. Kemampuan pengambilan keputusan karir siswa kelas XI berada pada kategori tinggi yaitu $43,66 \%$.

4. Terdapat hubungan yang positif dan signifikan antara self determination siswa dengan kemampuan pengambilan keputusan karir siswa SMA kelas XI.

5. Tidak terdapat hubungan antara motivasi berprestasi dengan kemampuan pengambilan keputusan karir siswa SMA kelas XI.

6. Terdapat hubungan yang positif dan signifikan antara self determination dan motivasi berprestasi terhadap kemampuan pengambilan keputusan karir siswa SMA kelas XI.

Berdasarkan hasil yang diperoleh dari penelitian ini, peneliti dapat dapat menyarankan beberapa hal yaitu sebagai berikut. Siswa dapat mengambangkan kemampuan pengambilan keputusan karir dalam hidupnya perlu dukungan dari berbagai pihak, khususnya sekolah sebagai lembaga pendidikan formal. Sekolah sebagai lembaga pendidikan yang bertujuan untuk memaksimalkan potensi siswa sebagai seorang individu yaitu dengan memfasilitasi kebutuhan perkembangannya yaitu melalui sistem pembelajaran yang mengaktifkan siswa. Pengaktifan siswa disini lebih fokus pada proses pembelajaran yang memberikan kesempatan pada siswa untuk dapat mengungkapkan pola pikir, pola rasa, dan pola tindak yang diberikan kebebasan dengan disertai tanggung jawab; menyediakan fasilitas yang memberikan akses kepada siswa dalam memperoleh informasi karir seperti akses melalui media internet atau bekerja sama dengan beberapa perguruan tinggi dan atau kantor-kantor agar apat memberikan informasi karir yang nyata kepada siswa. Selain itu, sekolah perlu mengadakan dan melibatkan orang tua dalam pertemuan-pertemuan karir disekolah, seperti selain mengadakan edufair untuk siswa dapat sekaligus melakukan pertemuan dengan orang tua sehingga informasi karir yang diperoleh memiliki kesamaan persepsi.

Konselor sekolah sebagai salah satu sumber informasi yang memiliki layanan bimbingan dan konseling karir hendaknya mengembangkan layanan karir yang proaktif. Konselor sekolah bekerja sama dengan personil sekolah untuk menyediakan informasi karir yang dibutuhkan siswa. Selain itu, konselor sekolah dapat melakukan asesmen awal seperti te bakatminat; asesment berbentuk iventori baik itu 
mengenal diri sendiri, writing reflection untuk melatih siswa agar mampu menganalisa baik tentang diri sendiri maupun karir; bimbingan karir yang berfokus pada pengembangan keterampilan self determination baik secara individual maupun dalam kelompok.

\section{DAFTAR PUSTAKA}

American School Counselor Association. (2005). The ASCA national model: A framework for school counseling programs (2nd ed.). Alexandria, VA: Author.

Benitez, et. al. (2005). Promoting The Involvement of Students With Emotinal and Behavioral Disorders in Career and Vacational Planning and Decision Making: The SelfDetermined Career Development Model. ProQuest Psychology Journals - Behavior Disorder, August 2005, Pages 431-447.

Cohen. (2003). Applying Existential Theory and Intervention to Career Decision Making. Journal of Career Development vol. 29: 195-209.

Danim, S. (2004). Motivasi, kepemimpinan, dan efektivitas kelompok. Jakarta: Rineka Cipta.

Evans, W.P., Brown, R., \& Killian, E. (2002). Decision Making and Perceived Postdetention Success Among Incarcerated Youth. Journal of Crime \& Delinquency, volume 48, pg: 553567

Field, S., Hoffman, A., \& Posch, M. (1997). Self-Determination during Adolescence A Developmental Perspective. Journal of Remedial and Special Education, Volume 18, Number 5, September/October 1997, Pages 285-293.

Fouad, et al. (2009). The Effectiveness of a Career Decision-Making Course. Journal of Career Assesment 2009 17: 338 originally published online
26 January 2009, Volume 17 Number 3, August 2009, Pages 338-347

Johnston, M. \& Finney S. (2010). Measuring basic needs satisfaction: Evaluating previous research and conducting new psychometric evaluation of the Basic Needs Satisfaction in General Scale. Journal of Contemporary Educational Psychology, Volume 35, pages 280296.

Kurniawan, I. (2011). Pengambilan Keputusan untuk Profesi pada Siswa Jenjang Pendidikan Menengah (Survei pada SMA, MA, dan SMK di DKI Jakarta) (Online). http://petamasadepanku.net/search/arti kel-hasil-penelitian-tentangpendidikan-kejuruan/ diakses pada tanggal 13 November 2013.

McClelland. (1987). Pengertian motivasi berprestasi. Diunduh dari http://fred1607.wordpress.com/2009/1 2/15/teori-motivasi-mcclelland-teoridua-faktor-hezberg/

Palmer, S \& Wehmeyer, M. (2003) Promoting Self-Determination in Early Elemntary School, Teaching Self-Regulated Problem-Solving and Goal-Setting Skills. Journal of Remedial and Special Education, Volume 24, Number 2, March/April 2003, Pages 115-126

Paolucci, B., Hall, O.A., \& Axinn, N. (1997). Family Decision Making: An Ecosystem Approach. New York: John Wiley and Sons.

Rowland, K. (2004). Career DecisionMaking Skills of High School Students In The Bahamas. Journal of Career Development, Volume 31, No.1, Fall 2004

Ridwan. (2003). Skala Pengukuran Variabel-Variabel Penelitian. Bandung: Alfabeta

Santrock. (2003). Remaja Edisi 11. Jakarta: Erlangga. 
Schunk, Pintrich, Meece. (2012). Motivasi dalam Pendidikan - Teori, Penelitian, dan Aplikasi, Edisi ketiga. Terjemahan. Jakarta: Penerbit Index.

Steinberg, J. 2009. Cognitive Psychology$\left(5^{\text {th }} \quad\right.$ Ed. $) . \quad$ Wadsworth: Cengage Learning.

Stanovich, K. 2010. Rational Thought and Behavior-Figuring Out What Is True and What to Do. New York: Oxford University Press

Sukadji. (2001). Pengertian motivasi berprestasi. Diunduh dari http://google.co.id/2011/10/12/pengert ian-motivasi-berprestasi

Sukmadinata, N. S. (2005). Landasan psikologi proses pendidikan. Bandung: Remaja Rosdakarya.

Supardi, S. (2013). Aplikasi Statistika Dalam Penelitian-Konsep Statistika yang lebih Komprehensif. Jakarta: Change Publication.

Winardi, J. (2004). Motivasi dan pemotivasian dalam manajemen. Jakarta: Raja Grafindo Persada. 
